AGRICULTURE AND BIOLOGY JOURNAL OF NORTH AMERICA

ISSN Print: 2151-7517, ISSN Online: 2151-7525, doi:10.5251/abjna.2011.2.5.773.779

(C) 2011, ScienceHuß, http://www.scihub.org/ABJNA

\title{
Functional properties of Artocarpus altilis pulp flour as affected by fermentation
}

\author{
${ }^{1}$ F. Appiah., ${ }^{2}$ I. Oduro and ${ }^{2}$ W. O. Ellis \\ ${ }^{1}$ Department of Horticulture and ${ }^{2}$ Department of Food Science and Technology, Kwame \\ Nkrumah University of Science and Technology, Kumasi, Ghana. \\ ${ }^{1}$ Corresponding author: fappiah_sp@yahoo.com \\ ABSTRACT
}

\begin{abstract}
A study was carried out to assess the effect of fermentation on functional properties of Artocarpus altilis pulp flour with the aim of expanding its use. Flours of unfermented and fermented A.altilis pulp were produced and standard procedures used to determine their functional properties. Fermentation resulted in significant decrease in bulk density from $0.57 \mathrm{~g} / \mathrm{cm}^{3}$ to $0.46 \mathrm{~g} / \mathrm{cm}^{3}$ and foam capacity from $9.2 \mathrm{~g} / \mathrm{ml}$ to $5.0 \mathrm{~g} / \mathrm{ml}$. In contrast, least gelation concentration and peak viscosity were increased from $0.4 \mathrm{w} / \mathrm{v}$ to $0.6 \mathrm{w} / \mathrm{v}$. and from $354.33 \mathrm{BU}$ to 616.67 respectively. Water absorption capacity $(3.33 \mathrm{ml} / \mathrm{g}-3.67 \mathrm{ml} / \mathrm{g})$, oil absorption capacity $(1.5 \mathrm{ml} / \mathrm{g}-2.5 \mathrm{ml} / \mathrm{g})$, solubility (7.3\%-11.55\%) and swelling power (7.02-8.72) were not significantly influenced by fermentation. The study shows that the functional properties (bulk density, least gelation concentration and peak viscosity) of $A$. altilis pulp flour can be enhanced through fermentation and hence their subsequent incorporation into food systems.
\end{abstract}

Keywords: Artocarpus altilis, functional properties, fermentation,

\section{INTRODUCTION}

Breadfruit (Artocarpus altilis) has been consumed in the Pacific as starchy staple (Taylor and Tuia, 2007) multiple and has been successfully introduced in Ghana (Gamedoagbao and Bennett-Lartey, 2007). Artocarpus altilis plays a major role in ensuring food security in the rural communities where they are predominant. It is high yielding with an average sized tree producing 400-600 fruits per year. Yields are superior to other starchy staples due in part to their verticality of production (NTBG, 2009). Singh (2009) reported that a single tree produces between 150 and $200 \mathrm{~kg}$ of food whereas Morton (1987) reported yields between 16 and 32ton/ha/year. Notwithstanding the high yielding potential, the crop is underutilized and considered as less important. The high water activity of the crop makes it easily susceptible to microbial attack (Amusa et al., 2002) as well as the bulky nature makes transportation difficult. This has prompted processing of the fruit into products such as flour. The production of breadfruit flour has shown to be useful technique in extending the shelf life. Conventional flours are known to play important functional roles in food systems. However, their rising cost has resulted in the search for alternative replacements to fully or partially substitute the conventional flours with non-conventional in foods has been reported (Chillo et al., 2008). This study was therefore, carried out to determine the effect of fermentation on functional properties of breadfruit. MATERIALS AND METHODS

Experimental Locations: All proximate determinations were carried out at the Biochemistry Department of the Crops Research Institute of the Centre for Scientific and Industrial Research at Fumesua. Functional properties were determined at the laboratories of Departments of Biochemistry and Biotechnology as well as Horticulture, Kwame Nkrumah University of Science and Technology, Kumasi, Ghana. Pasting characteristics were determined at the Food Research Institute, Accra. Mineral analysis was carried out at the Food Research Institute of Ghana, Soil Chemistry Laboratory and Biochemistry laboratory of School of Medical Sciences, KNUST, Kumasi, Ghana.

Sample Collection and Preparation: Artocarpus altilis fruits were collected from the Republic Hall of Kwame Nkrumah University of Science and Technology. Fresh firm and mature A.altilis fruits were harvested washed under running clean water and transported to laboratory for analyses.

Unfermented Artocarpus altilis flour preparation: The freshly harvested Artocarpus altilis fruits were peeled and sliced into cubes $\left(2 \mathrm{~cm}^{3}\right)$ under running tap water. The sliced pieces were dried in an oven 
(Wagtech oven (Model GP120SSE300HYD) at $50^{\circ} \mathrm{C}$ for 24 hours and then cooled to room temperature $\left(28^{\circ} \mathrm{C}\right)$. A hammer ill was used to mill the dried chips. The resultant flour was sieved through $75 \mu \mathrm{m}$ mesh and packaged in a sealed plastic bottle prior to analysis.

Fermented A. altilis flour preparation: Slices of A.altilis pulp were placed in distilled water in a ratio of 1:1 (w/v) for 12 hours and allowed to ferment spontaneously under ambient conditions $\left(28^{\circ} \mathrm{C}\right)$. Fermentation was continued for another 12 hours after decanting the water. The slices were then dried in an oven (Wagtech oven (Model GP120SSE300HYD) at $50^{\circ} \mathrm{C}$ for 24 hours. The dried chips were then milled in a hammer mill and sieved through 75 micometer mesh sieve. The flour was then packaged in plastic bottles prior to analyses.

\section{Determination of Functional Properties}

Bulk density: The method described by Oladele and Aina (2007) was used for the determination of bulk density. Fifty gram $(50 \mathrm{~g})$ of A.altilis pulp flour sample was put into $100 \mathrm{ml}$ measuring cylinder. The measuring cylinder was then tapped continuously on a laboratory table until a constant volume was obtained. Bulk density $\left(\mathrm{g} / \mathrm{cm}^{3}\right)$ was calculated using the formula:

$$
\text { Bulk density }=\frac{\text { Weight of sample }}{\text { Volume of sample after tapping }}\left(\mathrm{g} / \mathrm{ml} \mathrm{or} \mathrm{g} / \mathrm{cm}^{3}\right)
$$

Water and oil absorption capacities: Water and oil absorption capacities of the flour samples were determined by the method of Beuchat (1977) with slight modification. One gram of flour sample mixed with $10 \mathrm{~mL}$ of distilled water or oil in a preweighed 50 $\mathrm{mL}$ centrifuge tube. The suspension was agitated for one hour on a Griffin flask shaker after which it was centrifuged using Spectra Scientific centrifuge (Model: Merlin; SN 97 6137) for 15 minutes for $2200 \mathrm{rpm}$. The separated water or oil was then removed with a pipette and reweighing as recommended by (Sosulski et al., 1976). The water or oil absorption capacity was expressed as grams of water or oil absorbed per gram of the sample.

Swelling power and solubility: Swelling power and solubility were determined as described by Oladele and Aina (2007). One gram of A.altilis pulp flour was mixed with $10 \mathrm{ml}$ distilled water in a centrifuge tube and heated at $80^{\circ} \mathrm{C}$ for 30 minutes while shaking continuously. The tube was removed from the bath, wiped dry, cooled to room temperature and centrifuged for 15 minutes at 2200rpm. The supernatant was evaporated, and the dried residue weighed to determine the solubility. Solubility was determined using the formula:

Solubility $\%=$ (Weight of dried sample in supernatant/weight of original sample) x 100 .

The swollen sample (paste) obtained from decanting the supernatant was also weighed to determine the swelling power. Swelling power was calculated using the formula.

$$
\text { Swelling power }=\frac{\text { Weight of wet mass of sediment }}{\text { Weight of dry matter in the gel }}
$$

Foaming capacity and stability: Foam capacity was determined using the method of Lin (1974) with slight modification. Two grams of A.altilis pulp flour was mixed with $50 \mathrm{ml}$ distilled water in a $100 \mathrm{ml}$ measuring cylinder. The suspension was vigorously shaken to foam. Volume of foam (ml) after mixing was expressed as the foam capacity while volume of foam at 30minutes and 60 minutes after shaking was used as indicator of foam stability.

Least gelation concentration: Least gelation concentration for the various flour samples was determined using the method of Abbey and Ibeh (1988). Artocarpus altilis pulp flour was mixed with 5 $\mathrm{ml}$ distilled water in test tubes to obtain suspensions of $2-20 \%(w / v)$ concentration. The test tubes were then heated for 1 hour in a boiling water bath, cooled rapidly under running tap water and further cooled for 2 hours in a refrigerator at $4^{\circ} \mathrm{C}$. The least gelation concentration was regarded as that concentration at which the sample from the inverted test tube did not fall or slip.

Pasting characteristics : The pasting viscosity of the A.altilis pulp flours were determined using the method described by Damardjati and Luh (1987). The cooked paste viscosity of $14 \%$ slurries in $420 \mathrm{ml}$ water was measured using a Brabender amylograph (800141 OHG, Diusburg, Germany). The slurry was heated from $25-95^{\circ} \mathrm{C}$ at a uniform rate of $1.5 \mathrm{C} / \mathrm{min}$ under a constant stirring speed. The torque was continuously monitored. It was followed by cooling at a controlled rate of $1.5 \mathrm{C} / \mathrm{min}$ to $50^{\circ} \mathrm{C}$. Peak viscosity, setback value and gelatinization index were reported in Brabender Units (BU).

Statistical Analysis: Data on functional properties was analysed using Statistix 9 statistical software. One-way Student t-test was carried out and 
differences between treatments were reported at $p=0.01$. (Snedecor and Cochran, 1976).

\section{RESULTS AND DISCUSION}

\section{Functional Properties of A.altilis Flours}

Bulk density: Table 1 shows some functional properties of A.altilis pulp flour. The bulk density of the fermented flour $\left(0.57 \mathrm{gcm}^{-}{ }^{3}\right)$ was significantly higher $(p<0.01)$ than the unfermented $\left(0.46 \mathrm{gcm}^{-3}\right)$. The bulk densities of the flours were within range $\left(0.49-0.63 \mathrm{~g} / \mathrm{cm}^{3}\right)$ reported for yam (Hsu et al., 2003).
The reduction in bulk density as a result of fermentation is similar to the observation of Elkhalifa et al. (2005) and Onimawo et al. (2003). Bulk density is a measure of heaviness of flour (Adejuyitan et al., 2009) and an important parameter that determines the suitability of flours for the ease of packaging and transportation of particulate foods (Shittu et al., 2005) as well as for infant formulations. According to Nelson-Quartey et al. (2007), low bulk density flours are desirable in infant food preparation. The low bulk density of the A.altilis flours therefore suggests they could be useful in infant formulations.

Table 1: The effect of fermentation on functional properties of A.altilis of pulp flour

\begin{tabular}{|l|l|l|l|l|l|l|}
\hline Sample & $\mathrm{BD}\left(\mathrm{g} / \mathrm{cm}^{3}\right)$ & $\begin{array}{l}\text { WAC } \\
(\mathrm{g} / \mathrm{g})\end{array}$ & $\begin{array}{l}\text { FC } \\
(\mathrm{ml})\end{array}$ & $\begin{array}{l}\text { OAC } \\
(\mathrm{g} / \mathrm{g})\end{array}$ & $\begin{array}{l}\text { SOLB } \\
(\%)\end{array}$ & SP \\
\hline Unfermented & $0.57 \pm 0.02 \mathrm{a}$ & $3.67 \pm 0.01 \mathrm{a}$ & $9.2 \pm 0.29 \mathrm{a}$ & $1.50 \pm 0.03 \mathrm{a}$ & $11.55 \pm 0.045 \mathrm{a}$ & $7.02 \pm 0.03 \mathrm{a}$ \\
\hline Fermented & $0.46 \pm 0.02 \mathrm{~b}$ & $3.33 \pm 0.29 \mathrm{a}$ & $5.0 \pm 0.00 \mathrm{a}$ & $2.50 \pm 0.43 \mathrm{a}$ & $7.30 \pm 0.2 .74 \mathrm{a}$ & $8.72 \pm 0.56 \mathrm{a}$ \\
\hline P value & 0.000 & 0.438 & 0.78 & 0.018 & 0.113 & 0.032 \\
\hline
\end{tabular}
power; Figures bearing different alphabets are significantly different at $p<0.01$

Water absorption capacity: There was a marginal reduction in water absorption capacity of the fermented A.altilis pulp flour. Whereas the unfermented flour had water absorption capacity of $367 \%(3.67 \mathrm{~g} / \mathrm{g})$, the fermented flour had $333 \%$ $(3.33 \mathrm{~g} / \mathrm{g})$. However, the observed difference was not significant $(P>0.01)$. In contrast, the water absorption capacity of the flours was higher than the $219 \%$ reported by Nelson-Quartey et al. (2007). The water absorption capacity of the A.altilis pulp flours (330$367 \%$ ) was within range for cassava pulp flour (171.3\%-551.2\%; Nwabanne, 2009). Water absorption capacity of flour is useful indicator of whether protein can be incorporated with the aqueous food formulations, especially, those involving dough handing (Osungbaro et al., 2010). Interactions of protein with water, is important to properties such as hydration, swelling power solubility, and gelation (Etudaiye et al 2009). The high water absorption capacity of the flours suggests they could be useful in soup formulations (Olaofe et al., 1998).

Oil Absorption Capacity: The oil absorption capacity of the flours increased marginally with fermentation from $1.50 \mathrm{~g} / \mathrm{g}$ to $2.50 \mathrm{~g} / \mathrm{g}$. The flour of A.altilis had similar oil absorption capacity as cassava (1.57g/g; Okezie and Bello, 1988) and lesser yam (1.9g/g; Ukpabi, 2010) but higher than raw fluted pumpkin flour (0.37g/g; Giami and Bekebain, 1992). According to Periago et al. (1998) pea also showed similar marginal increase in oil absorption capacity with fermentation. According to Lahl and Braun (1994) lipid binding is dependent on the surface availability of hydrophobic amino acids. Oil absorption capacity is important as oil acts as flavor retainer and gives soft texture to food improving mouth-feel (Ubbor and Akobundu, 2009; Aremu et al., 2006). Since the flours had good oil absorption capacity it suggests the presence of good lipophilic constituents and therefore may be suitable for production of sausage, soups and cakes (Aremu et al., 2006; Kinsella, 1979).

Solubility: The solubility values of the A.altilis pulp flours ranged between $7.30 \%$ and $11.55 \%$ for fermented and unfermented flours respectively. There was no significant difference between the fermented and unfermented flours. The solubility of unfermented cassava flour was lower whereas the fermented was higher than native cassava $(8.65 \%$; Osungbaro et al., 2010). On the other hand, Baafi and Safo-Kantanka (2007) reported solubility ranging between $7.57 \%$ and $10.46 \%$ for cassava. According to the authors solubility of flour is an indicator of its quality. The high solubility (11.55\%) of the unfermented flour suggests it is digestible and 
therefore could be suitable for infant food formulations.

Swelling power: The swelling power values of A.altilis flour ranged between 7.02 and 8.72. No significant difference was observed between the fermented and unfermented pulp flours. The swelling power of A.altilis pulp flours was higher than 2.16 reported for cassava flour (Okezie and Bello, 1988). In contrast, Baafi and Safo-Kantanka (2007) reported solubility ranging between $17.16 \%$ and $20.08 \%$ for cassava pulp flour. High swelling power is an important criterion for good quality flour. Since the swelling power of A.altilis flours is high it suggests it may find application in noodle production (Mccomick et al., 1991).

Foam capacity and stability: The foam capacity and stability of both unfermented and fermented flours of A.altilis pulp has been presented in Figure 1. Fermentation resulted in reduced foam capacity from $9.2 \mathrm{mlg}^{-1}$ to $5.0 \mathrm{ml} \mathrm{g}^{-1}$. The foam capacity of the flours was lower than cassava pulp flour (13.70\%; Ubbor and Akobundu, 2009). Giami and Bekebain (1992) reported similar reduction in foam capacity in pumpkin. The flours had very poor foam stability. Akubor and Chukwu (1999) reported that foams are used to improve the texture, consistency and appearance of foods. According to Yasumatsu et al. (1972), foam formation and stability are dependent on $\mathrm{pH}$, viscosity, surface tension and processing methods. Foam stability is important since the usefulness of whipping agents depend on their ability to maintain the whip as long as possible (Lin et al., 1974). Since the flours have poor foam capacity and stability they might be poor foaming agents in foods requiring foamability such as koose.

Least gelation concentration: According to Gossette et al. (1984) gelation is an aggregation of denatured molecules. The least gelation concentration of unfermented A.altilis flour was 0.4 $(w / v)$ while fermented $A$. altilis was $0.6(w / v)$ as presented in Table 2. Elmoneim et al. (2005) similarly, observed that fermentation increased the least gelation concentration in sorghum flour. The ability of protein to form gels and provide structural matrix for holding water, flavors, sugars and food ingredients is useful in food application and in new product development (Aremu et al., 2006). Fermentation may have denatured the sorghum proteins and, thus, caused more aggregation than in the unfermented sorghum flour. Udensi (2001) indicated that gelation is a quality indicator influencing the texture of food such as moi -moi, agidi and soup. Flours with least gelation concentration are not suitable for infant formulation since they require more dilution and would result in reduced energy density in relation to volume (Onwulezo and Nwabuyu, 2009; Ezeji and Ojmelukwe, 1993). Since fermentation increased the flour concentration required for gel formation, the unfermented flours could be used in infant formulation to enhance nutrient density (Ezeji and Ojimelukwe, 1993). The results show that the unfermented flour would be a good gel-forming or firming agent, and would be useful in food systems such as pudding and snacks which require thickening and gelling. The unfermented flour may be suitable for Tatale production where it might gel and provide body. It might also be a useful glazing agent..

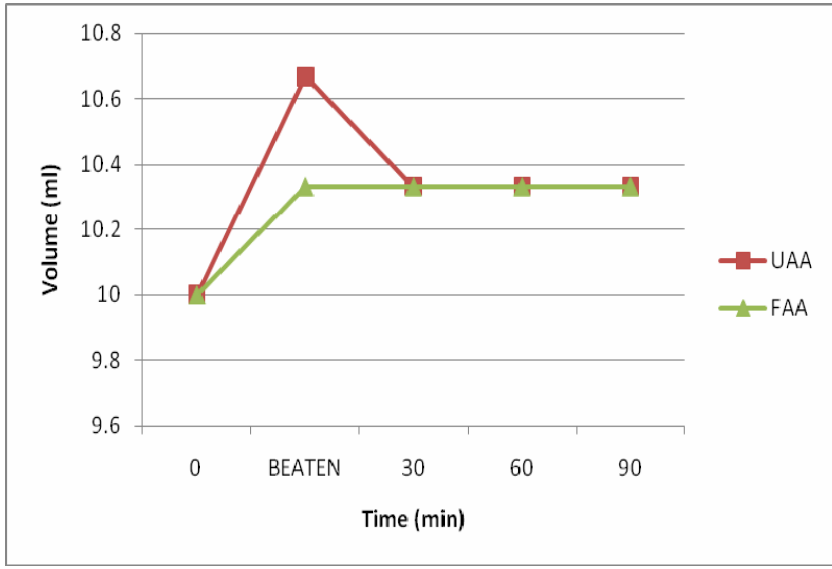

UAA - Unfermented A.altilis pulp flour FAA - Fermented A.altilis pulp flour

Fig 1. Effect of fermentation on foam capacity and stability of $A$.altilis flours 
Table 2: The effect of fermentation on least gelation concentration of $A$. altilis pulp flours

\begin{tabular}{|l|l|l|l|l|l|l|l|l|l|l|l|l|}
\hline Concentration & 0.1 & 0.2 & 0.3 & 0.4 & 0.5 & 0.6 & 0.7 & 0.8 & 0.9 & 1.0 & LGC \\
\hline Unfermented & $\mathrm{NV}$ & $\mathrm{V}$ & $\mathrm{V}$ & $\mathrm{G}$ & $\mathrm{G}$ & $\mathrm{G}$ & $\mathrm{G}$ & $\mathrm{G}$ & $\mathrm{G}$ & $\mathrm{G}$ & 0.4 \\
\hline Fermented & $\mathrm{NV}$ & $\mathrm{V}$ & $\mathrm{V}$ & $\mathrm{V}$ & $\mathrm{V}$ & $\mathrm{G}$ & $\mathrm{G}$ & $\mathrm{G}$ & $\mathrm{G}$ & $\mathrm{G}$ & 0.6 \\
\hline
\end{tabular}

Pasting characteristics of A.altilis flours: Table 3 shows the pasting characteristics of the A.altilis flours. All the viscosity parameters measured were higher in the fermented flour compared to the unfermented. The peak viscosity was significantly increased by fermentation from 354.33BU to 616.67BU. This indicates that the fermented flour formed thicker pastes. This is attributable to the marginally higher swelling power (8.72) observed in fermented A.altilis flour compared to 7.02 in unfermented A.altilis flour (Table 1) in this study (Otegbayo et al., 2006). According to Ayenor (1985) high swelling capacity might be due to weak internal bonding in starch granule. Fermentation resultes in weakened internal bonding in the starch of the fermented A.altilis resulting in higher peak viscosity
(Otegbayo et al., 2006) leading to granule rupture and alignment due to mechanical shear. The results indicate that the fermented flour could be useful as a thickening agent. According to Mbata et al. (2009) a low viscosity food (less bulky) contains higher nutrient content since the quantity per unit volume of the food would be low. The unfermented flour had lower viscosity and might be suitable in foods where light thickening is required as in porridge.

The higher setback value for the fermented flour (190 $\mathrm{BU})$ suggests it might be more resistant to breakdown in viscosity than the unfermented (84BU). This implies the cooked paste of the fermented flour would be more stable (Oduro et al., 2000). The flour could be suitable for thick porridge preparation.

Table 3: The effect of fermentation on pasting properties of A.altilis pulp flour

\begin{tabular}{|c|c|c|c|c|c|c|c|c|c|c|}
\hline & PT & BG & PV & SHP & $\mathrm{EFH} / \mathrm{FV}$ & SCP & SB & BD & TPV & TTPV \\
\hline Unfermented & $73.20 a$ & $14.67 \pm 2.31 \mathrm{a}$ & $354.33 \pm 9.87 a$ & $43.67 \pm 2.51 a$ & $385.33 a$ & $10.00 \pm 4.58 a$ & $84.00 \pm 6.93 a$ & $43.67 a$ & $94.13 a$ & 1798.3a \\
\hline Fermented & $72.47 b$ & $18.00 \pm 1.73 a$ & $616.67 \pm 4.04 b$ & $66.33 \pm 16.74 a$ & $614.67 b$ & $43.00 \pm 15.59 b$ & $190.00 \pm 0.00 \mathrm{~b}$ & $90.00 b$ & $93.83 a$ & $1791.7 a$ \\
\hline$P=0.01$ & 0.004 & 0.117 & 0.000 & 0.081 & 0.001 & 0.002 & 0.000 & 0.010 & 0.795 & 0.898 \\
\hline
\end{tabular}

Key: BG-Beginning of gelation; PV-Peak viscosity; SHP-Stability of hot paste; EFH/FV-final viscosity; SCP-Stability of cold paste; SB-Setback; BD-Breakdown; PT-Pasting temperature $\left({ }^{\circ} \mathrm{C}\right)$; Pt-Pasting time (seconds); TTPV-time taken to reach peak viscosity; Figures bearing different alphabets are significantly different at $p<0.01$

The pasting temperatures of the flours were $73.20^{\circ} \mathrm{C}$ and $72.47^{\circ} \mathrm{C}$ for unfermented and fermented flours respectively. These values are within range reported for maize $\left(69-78^{\circ} \mathrm{C}\right)$ by Sefa-Dedeh et al. (2004) but higher than that reported for cassava pulp flour $(62.0$ ${ }^{\circ} \mathrm{C}$ ) by Ubbor and Akobundu, 2009). Pasting temperature gives an indication of the temperature at which the flour would be cooked. The results suggest that the flours would cook at higher temperature than cassava.

\section{CONCLUSION}

The low bulk densities as well as the high solubility are indicative that the A.altilis pulp flours would be useful in formulation of infant meals. Since the flours had high oil absorption capacity they may find application in sausage production where oil binding is needed. Fermentation reduced bulk density but. The results of this study show that the fermentation increased least gelation concentration, peak viscosity, setback and pasting temperature while reducing bulk density of the A.altilis pulp flour. Fermentation could therefore be used to process A.altilis pulp for the production of flours for food formulations where thickening is desirable. Since Artocarpus altilis pulp flour has good functional properties its promotion for use in food formulation would expand its use.

\section{ACKNOWLEDGEMENT}

The authors are grateful to African Forestry Research Network (AFORNET) for providing financial assistance for this study.

\section{REFERENCES}

Abbey, B.W. \& Ibeh, G.O. (1988): Functional properties of raw and eat processed cowpea (Vigna unguiculata),Walp) flour. Journal of Food Science 53: 1775-1777. 
Adejuyitan, J. A., Otunola, E. T., Akande, E. A., Bolarinwa, I. F. and Oladokun, F. M. (2009). Some physicochemical properties of flour obtained from fermentation of tigernut (Cyperus esculentus) sourced from a market in Ogbomoso, Nigeria. African Journal of Food Science. Vol 3(2): 51-055.

Akubor, P. I. and Chukwu, J. K. (1999). Proximate composition and selected functional properties of fermented and unfermented African oil bean (Pentaclethra macrophylla) seed flour. Plant Foods for Human Nutrition 54 (3): 227-238.

Amusa, N. A., Kehinde, I. A. and Ashaye, O. A. (2002). Biodeterioration of breadfruit (Artocarpus communis) in storage and its effects on the nutrient composition. African Journal of Biotechnology 1 (2): 57-60.

Aremu, M. O., Olonisakin, A; Atolaye, B. O and Ogbu, C. F. (2006). Some nutritional and functional studies of Prosopis africana. Electronic Journal of Environmental, Agricultural and Food Chemistry 5(6):1640-1648.

Ayenor, G. S. (1985). The yam (Dioscerea) starches. In G. Osuji (Ed.), Advances in yam research: the biochemistry and technology of the yam tuber. Biochemical Society of Nigeria and Anambra State University of Technology. Enugu, Nigeria pp. 79-88.

Baafi, E. and Safo-Kantanka, O. (2007). Effect of genotype, age and location on cassava flour yield and quality. $\mathrm{J}$. Plant Sci., 2: 607-612.

Beuchat, L.R. (1977). Functional and electrophoretic characteristics of succinylated peanut flour protein, $\mathrm{J}$. Agric. Food Chem. 25: 258-261.

Chillo, S. , Laverse, J., Falcone, P.M. and Nobile, M.A. D. (2008). Quality of spaghetti in base amaranthus wholemeal flour added with quinoa, broad bean and chick pea. Journal of Food Engineering 84 (1): 101107.

Damardjati, D. S. and Luh, B. S. (1987). Physicochemical properties of Extrusion-cooked rice breakfast cereals. Proceeding of the $7^{\text {th }}$ World Congress of Food Science and Technology. Trends in Food Processing 1: Membrane Filtration Technology and Thermal Processing and Quality of Foods. Singapore. October. A. A. Ghee et al (Eds.). pp. 251-264.

Elkhalifa, A. E. O., Schiffler B. and Bernhardt, R. (2005). Effect of fermentation on the functional properties of sorghum flour. Food Chemistry 92 (1): 1-5

Elmoneim, A., Elkhalifa, O., Schiffler, B. and Bernhardt, R. (2005). Effect of fermentation on the functional properties of sorghum flour. Food Chemistry 92: 1-5.

Etudaiye, H. A., Nwabueze, T. U. and Sanni, L. O. (2009). Quality of fufu processed from cassava mosaic disease
(CMD) resistant varieties African Journal of Food Science 3 (3):61-67

Ezeji, C. and Ojimelukwe, P. C. (1993). Effect of fermentation on the nutritional quality and functional properties of infant food formulations prepared from bambara-groundnut, fluted pumpkin and millet seeds. Plant Foods for Human Nutrition 44: 267-276.

Gamedoagbao, D. K. and Bennett-Lartey, S.O. (2007). Conservation and use of breadfruit: Ghanaian perspective. Acta Horiculturae (ISHS) 757:125-128 [http://www.actahort.org/books/757/757_16.htm] [accessed $28^{\text {th }}$ August, 2009]

Giami, S. Y. and Bekebain, D. A. (1992). Proximate composition and functional properties of raw and processed full-fat fluted pumpkin (Telfariria occudentalis) seed flour, Journal of the Science of Food and Agriculture 59 (1992), pp. 321-325.

Gossett, P.W., Rizvi, S.S.H. and R.C. Baker (1984). Quantitative Analysis of Gelation in Egg Protein Systems Food Technology 38 (5): 67-96.

Hsu, C-L., Chen' W., Weng, Y-M and Tseng, C-Y. (2003). Chemical composition, physical properties, and antioxidant activities of yam flours as affected by different drying methods. Food Chemistry 83 (1): 8592.

Kinsella, J. E. (1979). Functional properties of soy proteins. Journal of the American Oil Chemists Soceity 56 (3): 242-258.

Lahl, W. J. and Braun, S. D. (1994). Enzymatic production of protein hydrolysates for food use. Food Technology 48: 68-71.

Lin, M. J. Y., Humbert, E. S. and Sosulki, F. W. (1974). Certain functional properties of sunflower meal product. Journal of Food Science 39: 368-370.

Mbata, T. I., Ikenebomeh, M. J. and Ezeibe, S. (2009). Evaluation of mineral content and functional properties of fermented maize (Generic and specific) flour blended with bambara groundnut (vign subterranean L). African Journal of food Science 3(4): 107-112

McComick, K. M., Panozzo, J. F. and Hong, S. H. (1991). A swelling power test for selecting potential noodle quality wheats. Australian Journal of Agricultural Research 42 (3): 317-323.

Morton, J. (1987). Breadfruit: Fruits of Warm Climates, Jr .Dowling, CF. (Ed.). Greensborough, US: Media Incorporated. pp: 50-63.

Narayana, K, Narasinga Rao MS (1982). Functional properties of raw and heat processed winged bean flour. Journal of Food Science 47: 1534-1538. 
Nelson-Quartey, F. C., Amagloh, F. K., Oduro, I. and Ellis, W. O. (2007). Formulation of an infant food based on breadfruit (Artocarpus altilis) and breadnut (Artocarpus camansi). Acta Horticulturae. (ISHS) 757:212-224.

NTBG (2009). Hunger initiative. Breadfruit Institute. National Tropical Botanical Garden. [http://www.ntbg.org/breadfruit/hunger.php]

Nwabanne, J. T. (2009). Drying characteristics and engineering properties of fermented ground cassava African Journal of Biotechnology 8 (5): 873-876

Oduro, I., Ellis, W. O., Aryeetey, S. K., Ahenkora, K. and Otoo, J. A. (2000). Pasting characteristics of starch from new varieties of sweet potato. Tropical Science 40: 25-28.

Okezie, B. O. and Bello, A. B. (1988). Physicochemical and functional properties of winged bean flours and isolate compared with soy isolate. J. Food Sci. 53 (2) ; 445 450.

Oladele, A. K. and Aina, J. O. (2007). Chemical composition and functional properties of flour from two varieties of tigernut (Cyperus esculentus). African Journal of Biotechnology. 6(21): 2473-2476

Olaofe, O., Adeyemi, F. O. and Adediran, G. O. (1994). Amino acid and mineral and functional properties of some Oilseeds. Journal of Agricultural and Food Chemistry 42: 878-881

Onimawo, I.A., Nmerole, E.C., Idoko, P.I. and Akubor, P.I. (2003). Effects of fermentation on nutrient content and some functional properties of pumpkin seed (Telfaria occidentalis). Plant Foods for Human Nutrition 58(3): 1-9.

Onwulenzo, J. C. and Nwabugu, C. C. (2009). Fermentation of Millet (Pennisetum americanum) and Pigeon Pea (Cajanus cajan) seeds for flour production: Effects on composition and selected functional properties. Pakistan Journal of Nutrition 8(6): 737-744

Osungbaro, T. O; Jimoh, D. and Osundeyi, E. (2010). Functional and Pasting Properties of Composite Cassava-Sorgum Flour Meals. Agriculture and Biology Journal of North America 1(4): 715-720

Otegbayo, B., Aina, J., Asiedu, R. and Bokanga, M. (2006). Pasting characteristics of fresh yams (Dioscerea spp.) as indicators of textural quality in a major food product - 'pounded yam'. Food Chemistry 99: 663-669.

Periago, M. J. Vidal, M. L, Ros, G., Rincon, F., Martinez, C., Lopez, G., Rodrigo, J. and Martinez, I. (1998).
Influence of enzymatic treatment on the nutritional and functional properties of pea flour. Food Chemistry 63 (1): 71-78.

Sefah-Dedeh, S., Cornelius, B., Sakyi-Dawson, E. and Ohene Afoakwa, E. (2004). Effect of nixtamalization on the chemical and functional properties of maize. Food Chemistry 86: 317-324.

Shittu, T.A., Sanni, L.O., Awonorin, S. O., Maziya-Dixon, B. and Dixon, A. (2005). Use of multivariate techniques in studying flour making characteristics of some Cassava Mosaic Disease resistant cassava clones. African Crop Science Conference Proceedings, Vol. 7. pp. $621-630$

Singh, H. (2009). Tapping into breadfruit's bounty. Available online at: http://www.universityaffairs.ca/tapping-intobreadfruits_bounty.aspx

Snedecor, G. W. and Cochran, W. G. (1976). Statistical Methods, pp. 258-275, lowa State University Press, Ames, IA

Sosulski, F.W., Humbert, E.S., Bui, K. and Jones, J.O. (1976). Functional properties of rapeseed flour concentrates and isolates. J. Food Sci., 41: 13481354.

Taylor, M. B. and Tuia, V. S. (2007). Breadfruit in the Pacific Region. Proceedings of the $1^{\text {st }}$ International symposium on breadfruit research and Development. Eds. D. Ragone and M. B. Taylor. Acta Horticulturae. (ISHS) 757:43-50.

Ubbor, S.C. and Akobundu, E.N.T. (2009). Quality Characteristics of Cookies from Composite Flours of Watermelon Seed, Cassava and Wheat. Pakistan Journal of Nutrition 8 (7): 1097-1102.

Udensi, E. A., Eke, O. and Ukachukwu, S. N. (2001). Effect of traditional processing on the physicochemical properties of Mucuna cochinchinensis and Mucuna Utilis flours. Journal of Agriculture,. Food Technoogy and Environment 1: 133-137.

Ukpabi, U. J. (2010) Farmstead bread making potential of lesser yam (Dioscorea esculenta) flour in Nigeria Australian Journal of Crop Science 4(2):68-73

Yasumatsu, K., K. Sawada., Moritaka, S., Mikasi, M., Toda, J., Wada , T. and Ishi, K. (1972). Whipping and emulsifying properties of soybean products. Agricultural and Biological Chemistry 36: 719-727. 